Proc. Estonian Acad. Sci. Eng., 2001, 7, 3, 195-211

\title{
EXTREME WIND SPEEDS AND SPATIALLY UNIFORM WIND EVENTS IN THE BALTIC PROPER
}

\begin{abstract}
Tarmo SOOMERE
Estonian Marine Institute, Paldiski mnt. 1, 10137 Tallinn, Estonia; tarmo@phys.sea.ee

Received 20 February 2001, in revised form 25 May 2001

Abstract. It is shown that Vilsandi wind data represent satisfactorily both scalar and directional properties of the wind regime in the Baltic Proper. Angular distribution of the wind speed in extreme wind events (based on the Weibull distribution) has a specific two-peaked shape with maxima corresponding to south-west and north winds, and a deep minimum for eastearly winds. Extensive periods in which wind direction is uniform over large areas, frequently occur in the Baltic Proper. Both wind speed and direction may essentially change during such events, but the changes may occur synchronously at remote sites.
\end{abstract}

Key words: wind dynamics, extreme wind speed, Baltic Sea meteorology.

\section{INTRODUCTION}

Basic dynamical properties of the sea state such as the water level, the pattern of currents, and the wave regime are most dependent on the wind regime. The wind field in Estonia and in the adjacent areas is traditionally interpreted as directionally homogeneous. Indeed, the area in question is void of large-scale effects and serves as a prolongation of the North Atlantic storm track $\left[{ }^{1,2}\right]$, where frequent occurrence of high-latitude cyclones causes high variability of the wind speed and direction. A slight prevalence of the west winds stems from the largescale western airflow at these latitudes. Interplay of the North Atlantic Low and the Siberian High causes dominance of the SW winds during certain seasons. The anisotropy is quite limited and frequency of the winds from different directions varies about $30 \%\left[{ }^{3-6}\right]$.

However, it is well known that the strongest storms in the Baltic Sea area blow from SW, west, or north. This anisotropy, studied to some extent in $\left[^{7}\right]$, becomes evident in seasonal wind roses. Indeed, the angular wind distribution in 
relatively stormy seasons contains larger part of SW (in the Baltic Proper) or SE (in the Gulf of Riga area) winds than in relatively calm April-June when the distribution is more or less isotropic $\left[{ }^{6,8,9}\right]$.

Recently, a highly anisotropic two-peaked angular distribution of parameters of moderate $(6-10 \mathrm{~m} / \mathrm{s})$ and strong $(>10 \mathrm{~m} / \mathrm{s})$ winds has been established for the northern Baltic Proper $\left[{ }^{10}\right]$ (whereas the more or less isotropic shape of traditional wind roses apparently is caused by weak winds). Although the time series used in $\left[{ }^{10}\right]$ are somewhat shorter than is usual in climatological studies, the existence of the specific angular wind structure in the Baltic Sea area is likely since the distributions of the maximum wind speed, frequency of events of moderate and strong winds, and mean wind speed at both sides of the Baltic Proper qualitatively coincide. The specific wind regime is not connected with local peculiarities of the geostrophic wind (that generally has one maximum for westerly winds and only in April-September secondary peaks exist for NE and east winds $\left.\left[{ }^{8,11,12}\right]\right)$.

The analysis in $\left[{ }^{10}\right]$ revealed the existence of the anisotropic wind regime as a statistical feature and discussed several of its consequencies for wave prediction. However, it was not established whether at a certain instant the wind speed and direction at different sites coincide and does it have any dynamical consequencies at all. This paper addresses further questions arising from this statistical feature. Are measurements in the coastal zone reliable for estimating wind regimes off the coast? What are reliable values of the maximum wind speed during $10,20,50$, or 100 years? Is the prevailing wind direction simply a statistical feature or it is connected with certain large-scale dynamical weather patterns? Is the regime permanently active or are long-term deviations from it possible?

For correct estimation of the current patterns and parameters of the wave field off the shore, one needs a reliable picture of the wind regime at open sea, where wind properties may greatly differ from those in mainland. The analysis in Section 2 and in $\left[{ }^{10,13,14}\right]$ suggests that, among other coastal measurement sites, Vilsandi wind data reasonably represent wind regime off the coast of the Saaremaa Island. However, the wind regime at Undva Cape in September-November 2000 (during the field campaign of the hydrodynamical and geological studies of the Saaremaa deep harbour $\left[{ }^{15}\right]$ ) was completely different from the climatologically mean one in terms of both mean wind speed and directional structure of winds.

In Section 3, directional distribution of extreme wind speeds off the NW coast of Saaremaa is analysed using the Weibull distribution on the basis of the Vilsandi data. One of the consequences of the highly anisotropic wind distribution is the existence of extensive and persistent wind patterns with constant direction over large areas (Section 4). In Section 5, it is shown that even moderate storms may be uniform in the whole Baltic Proper during several days. Both the wind speed and direction may change essentially during such events but the changes occur synchronously at distant sites. This is an amazing property since high-resolution wind measurements in the coastal area of Estonia confirm that rapid changes of the wind speed at different sites are mostly incoherent $\left[{ }^{13}\right]$. 


\section{CLIMATOLOGICAL WIND PARAMETERS IN THE COASTAL ZONE OF THE BALTIC PROPER AND IN ADJACENT AREAS}

Since no long-term wind measurements have been performed off the western coast of Estonia, data from coastal meteorological stations must be used for estimating the climatological wind regime at open sea. The analysis below relies on four data sets. Climatological wind parameters are estimated using 15-year (1976-1991) recordings at Vilsandi and Ristna weather stations (Fig. 1a). Wind regime in the Gulf of Riga and Moonsund area is analysed on the basis of measurements at Sõrve, Virtsu, and Pärnu weather stations in 1992-1995 [ $\left.{ }^{9}\right]$. Wind speed and direction at these sites have been filed averaged over 10-min periods once at every three hours starting from 0000 GMT. Although only data for $0000,0600,1200$ and 1800 GMT is used below, the analysis in $\left[{ }^{14}\right]$ suggests that this data represent well long-term wind dynamics. The angular resolution of the filing is $22.5^{\circ}$ (16 directions). The data were compared with hourly averaged wind speed and direction measured at the height of $38 \mathrm{~m}$ at Näsudden (Gotland, 1980-1989) located at a distance of $300 \mathrm{~km}$ from Vilsandi. Additionally, highresolution wind data (continuously measured and filed as an average over 10-min periods during the hydrodynamical and geological studies of Saaremaa deep harbour sites in September-December, $2000\left[{ }^{15}\right]$ ) from Undva Cape, located at a dozen of kilometers from Vilsandi and totally open to sea, are used.

Wind data at Näsudden are measured at seven different levels of a $144 \mathrm{~m}$ high tower located in the coastal area of Gotland. Thus, wind regime at the higher levels apparently represents well that of the open sea. Both scalar and directional parameters of the wind properties at Vilsandi are close to those of the wind field at $38 \mathrm{~m}$ level at Näsudden. The coincidence is particularly important since completely different measurement routines were used at these sites. Mean wind speed at Näsudden and Vilsandi (as well as at Sõrve) is 6-7 m/s (Table 1). At Ristna the mean wind speed is by $20-30 \%$ lower than at neighbouring sites
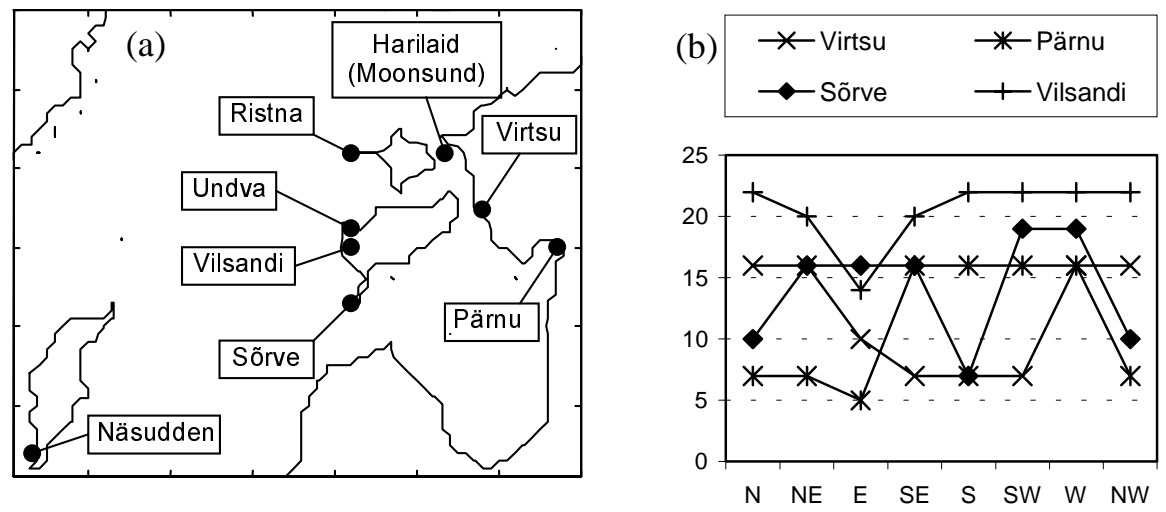

Fig. 1. Location of measurement sites (a) and angular distribution of the rate of free flow at these sites (b) $\left[{ }^{6}\right]$. Maximum rate is 25 (no obstacles nearby). 
apparently due to obstacles nearby. An amazing feature is that the frequency of occurrence of moderate and strong winds at Näsudden and Vilsandi is practically identical (53-54\% for wind speeds $u \geq 6 \mathrm{~m} / \mathrm{s}$ and about $17 \%$ for $u>10 \mathrm{~m} / \mathrm{s}$, Table 1), whereas at Ristna weak winds dominate (probability of $u \geq 6 \mathrm{~m} / \mathrm{s}$ is $24 \%$ and of $u>10 \mathrm{~m} / \mathrm{s}-4.7 \%$ ). Another important feature of Vilsandi is that wind does not vanish at night. Mean wind speed at 0000 is $6.2 \mathrm{~m} / \mathrm{s}$, at $0600-6.26 \mathrm{~m} / \mathrm{s}$, at $1200-6.64 \mathrm{~m} / \mathrm{s}$, and at $1800-6.42 \mathrm{~m} / \mathrm{s}$. This feature is typical for areas where open sea wind dominates. Also, directional distributions of wind properties at Vilsandi and Näsudden are very similar (whereas only east wind is somewhat damped at Vilsandi $\left.\left[{ }^{10}\right]\right)$. The traditional wind rose is more or less isotropic at all measurement sites, but the directional distributions of moderate $(6-10 \mathrm{~m} / \mathrm{s})$ and strong $(>10 \mathrm{~m} / \mathrm{s})$ winds are highly anisotropic. For Vilsandi and Näsudden data, they have the two-peaked shape typical for the Baltic Proper. An extremely high peak corresponds to SW winds and a somewhat lower peak to north winds (Fig. 2). At Ristna, SW winds dominate among moderate winds whereas both north and NE winds are about 10 times less frequent than SW winds. Thus, apparently Vilsandi data represent well the wind regime at open sea in the northern Baltic Proper (perhaps except east winds) whereas the Ristna data evidently do not.

Data from weather stations at Sõrve, Pärnu, and Virtsu (1992-1995) as well as the basic wind properties at Harilaid Islet (1997-1998) $\left[{ }^{13}\right]$ show that mean wind speed in the Moonsund and Gulf of Riga areas is either comparable (Harilaid, Sõrve) or less (Virtsu, Pärnu) than that in the Baltic Proper (Table 1). Directional distributions of wind events in these areas differ from those in the Baltic Proper. (The term "wind event" means here an actual wind field at a measurement site represented by a single record, and is not related to strong winds only.) Apart from general dominance of the SW winds in the whole region, a minor maximum exists corresponding to east or NE winds at Sõrve, Virtsu, and Pärnu. In Moonsund, the minor peak exists only for SE winds $\left[{ }^{13}\right]$. The distributions in Fig. 2 are uncorrelated with the angular distribution of the rate of free flow (Fig. 1b). Thus, the minor minima for SE and NE winds and the local maximum for east winds apparently are characteristic features of the wind regime in the Gulf of Riga region.

Table 1. Mean wind speed at different measurement sites

\begin{tabular}{l|c|c|c|c|c}
\hline $\begin{array}{c}\text { Measurement } \\
\text { site }\end{array}$ & $\begin{array}{c}\text { Height, } \\
\mathrm{m}\end{array}$ & Used data & $\begin{array}{c}\text { Mean wind } \\
\text { speed, } \mathrm{m} / \mathrm{s}\end{array}$ & $\begin{array}{c}\text { Frequency of } \\
\text { winds } \geq 6 \mathrm{~m} / \mathrm{s}, \\
\%\end{array}$ & $\begin{array}{c}\text { Frequency of } \\
\text { winds }>10 \mathrm{~m} / \mathrm{s}, \\
\%\end{array}$ \\
\hline Undva & 18 & $09-12 / 2000$ & 5.49 & 39.46 & 4.95 \\
Vilsandi & 10 & $1977-1991$ & 6.40 & 53.86 & 16.69 \\
Ristna & 10 & $1977-1991$ & 4.25 & 24.00 & 4.70 \\
Sõrve & 10 & $1992-1995$ & 6.63 & 57.75 & 13.18 \\
Pärnu & 10 & $1992-1995$ & 3.82 & 16.00 & 0.28 \\
Virtsu & 10 & $1992-1995$ & 4.33 & 25.08 & 1.78 \\
Harilaid [ $\left.{ }^{14}\right]$ & $20 / 35 / 50$ & $09 / 1997-09 / 1998$ & $7.11 / 7.55 / 7.98$ & - & - \\
Näsudden & 38 & $1980-1989$ & 6.90 & 52.75 & 16.7
\end{tabular}



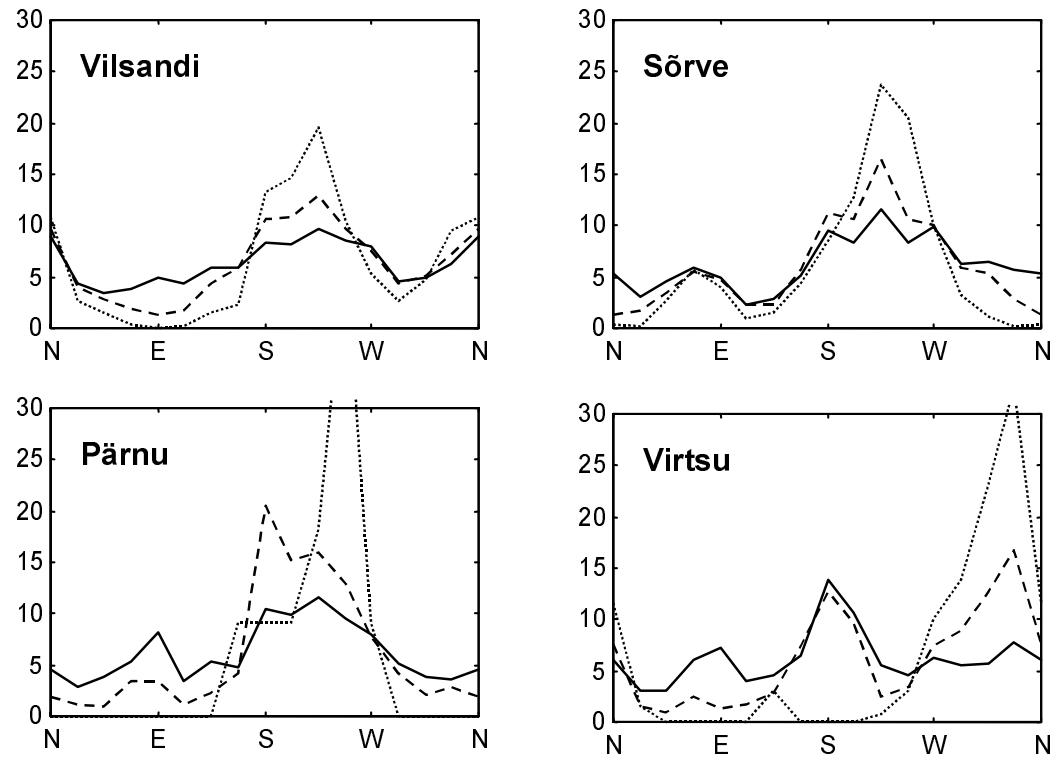

Fig. 2. Angular distribution of the frequency (\%) of winds at Vilsandi (1977-1991), Sorrve (1992-1995), Pärnu (1992-1995), and Virtsu (1992-1995) weather stations; — all wind events, $---u \geq 6 \mathrm{~m} / \mathrm{s}, \cdots \cdot u>10 \mathrm{~m} / \mathrm{s}$.

The angular distribution of moderate and strong $(\geq 6 \mathrm{~m} / \mathrm{s})$ winds shows certain variability in the Gulf of Riga area. At Pärnu and Sõrve, SW winds dominate whereas a minor peak for east winds is also present. At Virtsu, the distribution has a two-peaked shape where south and NNW winds have equal frequency. The angular distribution of strong winds is extremely anisotropic at all sites. At Pärnu and Sõrve, most of the storms blow from SW whereas at Sõrve the minor peak for NE winds is still present. The overwhelming domination of north winds among strong winds at Virtsu is apparently connected with obstacles in all other directions except the northern one (Fig. 1b). Also, it does not become evident at open sea in the Moonsund area $\left[{ }^{14}\right]$. Thus, wind regimes in the Baltic Proper and Gulf of Riga are apparently somewhat different. The specific feature of the Gulf of Riga area is the high frequency and intensity of SW winds combined with relatively frequent east winds.

Comparison of the wind data, filed during the measurement campaign in September-November 2000 at Undva Cape, with Vilsandi data shows that the wind speed at Undva (although measured at a relatively high level) was well below its climatological mean value (Fig. 3, Table 1). Although November is the most stormy month in the area in question, the wind regime resembled more the one during summer months. Only in December wind speed increased to a certain extent but still remained $15 \%$ lower than is typical for December. Also, directional structure of winds at Undva differs much from that typical for these 


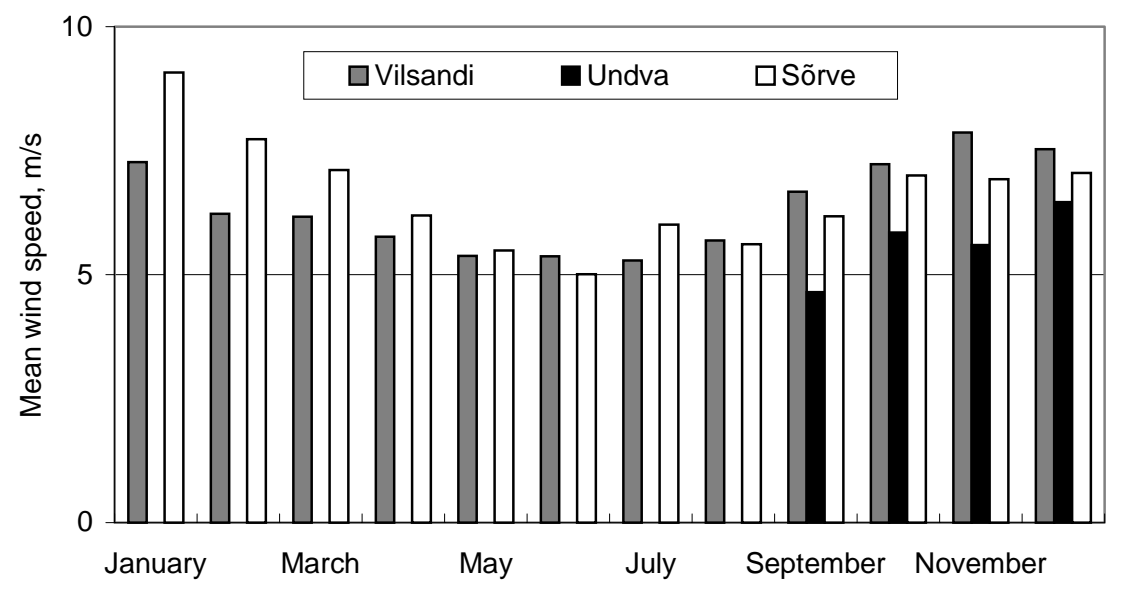

Fig. 3. Monthly mean wind speed at Vilsandi (1977-1991), Sõrve (1992-1995), and Undva (September-December 2000).
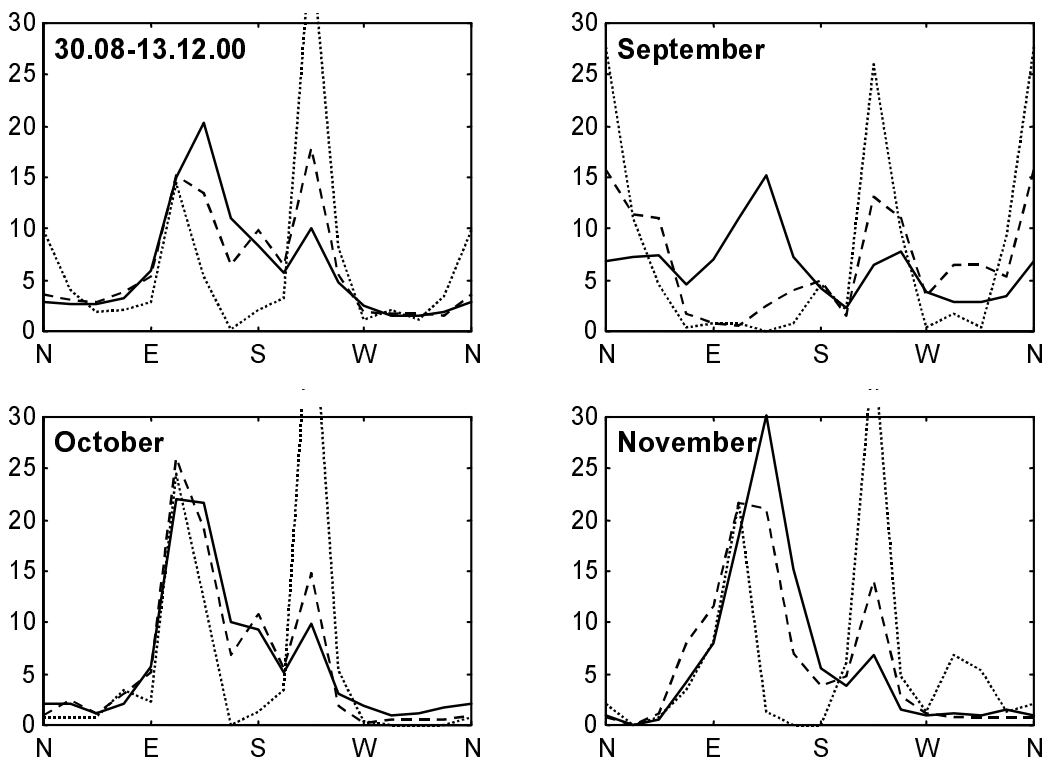

Fig. 4. Angular distribution of the frequency (\%) of winds at Undva Cape during the measurement period 30.08-13.12.00 and different months: - all wind events, ---- $u \geq 6 \mathrm{~m} / \mathrm{s}, \cdots \cdots u>10 \mathrm{~m} / \mathrm{s}$. 
months. Monthly wind roses for Vilsandi demonstrate prevalence of SW and north winds during September-October whereas wind roses for DecemberJanuary have more or less isotropic shape $\left[{ }^{10}\right]$. At Undva, SE winds prevailed during September and October, 2000 (Fig. 4). Only a minor peak corresponded to SW winds. North winds occurred a few times only in September. Such angular structure is typical for the Gulf of Riga during summer $\left[{ }^{9}\right]$. The directional distribution of moderate and strong winds somewhat resembles climatological distributions (Fig. 2). The share of SW winds is relatively high during all the months, and north storms occurred in September. However, in October and November SE winds prevailed also among moderate and strong winds.

This comparison indicates that essential deviations from the climatologically mean directional wind distribution may occur during relatively long time intervals.

\section{ANGULAR DISTRIBUTION OF EXTREME WIND PARAMETERS}

It is irrelevant to use climatological values of the maximum wind speed (that may reach $35-40 \mathrm{~m} / \mathrm{s}\left[^{2,15}\right]$ ) by estimating the maximum wave heights and wave loads on harbour constructions. These values mostly represent the wind speed in short gusps that last typically a few minutes whereas the saturation time of a wave field in the Baltic Proper is $6-8 \mathrm{~h}\left[{ }^{16}\right]$. Thus, extreme wave loads can be only computed on the basis of the (spatial and temporal) distribution of storms with a duration of at least $6 \mathrm{~h}$.

The available climatological data $\left[^{5,6}\right]$ carry insufficient information about directional variation of the extreme wind speed. Detailed analysis demonstrates that frequencies of strong winds from different directions in the coastal area of Estonia differ more than 10 times whereas the contrasts are much higher than described in historical data $\left[{ }^{10}\right]$. The directional distributions of the mean and extreme wind speeds in the Baltic Proper show low intensity of east and NW winds as compared to SW and north winds. The screening effect caused by mainland causes certain differences in the local wind regime at the coasts but the global minimum for east winds is clearly a specific feature of the wind regime in the Baltic Proper since it becomes evident overall in the meteorological data.

The above analysis shows that Vilsandi data represent well the main properties of the wind regime at the open sea. Only the uncommonly low maximum value of the east wind at Vilsandi $(11 \mathrm{~m} / \mathrm{s})$ may partly result from the screening effect of Saaremaa and Hiiumaa. Comparison with Näsudden $\left[{ }^{10}\right]$ suggests that realistic maximum east wind speed off the Saaremaa coast is $14-15 \mathrm{~m} / \mathrm{s}$. However, the damping of east winds at Vilsandi is unimportant in the context of wave prediction in the coastal zone of Estonia, since waves coming from east and NE directions are fetch-limited anyway.

The standard method for estimating extreme wind parameters is based on the Weibull (Gnedenko) distribution. The density function of this distribution is 
$f(u)=k u^{k-1} b^{-k} \exp \left[-(u / b)^{k}\right]$ where $u>0$ is the instantaneous wind speed and $k$ is the shape parameter. Notice that if $k=1$, the Weibull distribution reduces to the exponential distribution $f(u)=b^{-1} \exp (-u / b)$ with scale parameter $b$. The special case $k=2$ is called the Rayleigh distribution. The probability that the wind speed exceeds the value $U \mathrm{~m} / \mathrm{s}$ during the analysed period is $P_{u>U}=F(U)=\exp \left[-(U / b)^{k}\right]$.

The parameters of the Weibull distribution can be found from relations $u_{\mathrm{m}}=b \Gamma(1+1 / k)$ and $u_{\mathrm{ms}}=b^{2} \Gamma(1+2 / k)$, where $u_{\mathrm{m}}$ is the mean wind speed, $u_{\mathrm{ms}}$ is the mean value of the wind speed squared, and $\Gamma$ is the gamma function. In the North European climate, generally, $k \approx 2.0$ and the distribution is close to the Rayleigh distribution $\left[{ }^{17}\right]$. Indeed, at Vilsandi $k=2.048$ and $b=7.235$. These values are close to those for Näsudden $\left[{ }^{18}\right]$ for all winds but show considerable variations for different directions (Table 2).

Formally, the Weibull distribution gives the probability $P_{u>U}$ of the occurrence of instantaneous wind speed $u$ exceeding the value $U$ during the period in question. It is natural to interpret each wind record at Vilsandi (filed as the mean wind speed during a specific 10-min time interval four times per day) as the mean wind speed and direction during $6 \mathrm{~h}$. Equivalently, the probability $P_{u>U}$ shows how often the mean wind speed during $6 \mathrm{~h}$ exceeds $U$. Mean wind

Table 2. Parameters of the Weibull distribution for different wind directions at Vilsandi and Näsudden

\begin{tabular}{c|c|c|c|c}
\hline \multirow{2}{*}{ Direction, deg } & \multicolumn{4}{|c}{ Parameters of the Weibull distribution } \\
\cline { 2 - 5 } & \multicolumn{2}{|c}{$b$} & \multicolumn{2}{c}{$k$} \\
\cline { 2 - 5 } & Vilsandi & $\begin{array}{c}\text { Näsudden } \\
38 \mathrm{~m}\left[{ }^{18}\right]\end{array}$ & Vilsandi & $\begin{array}{c}\text { Näsudden } \\
38{\mathrm{~m}\left[{ }^{18}\right]}^{*}\end{array}$ \\
\hline All winds & 7.235 & 7.8 & 2.048 & 2.06 \\
20 & 6.6461 & - & 2.1892 & - \\
45 & 6.1484 & 6.5 & 2.1508 & 2.12 \\
70 & 5.2475 & - & 2.3199 & - \\
90 & 4.4075 & 6.1 & 2.6248 & 2.24 \\
110 & 4.8618 & - & 2.5158 & - \\
135 & 6.0490 & 6.1 & 2.4619 & 2.04 \\
160 & 6.7602 & - & 2.5443 & - \\
180 & 8.4502 & 7.5 & 2.3181 & 2.13 \\
200 & 8.7584 & - & 2.3056 & - \\
225 & 9.0186 & 8.3 & 2.2870 & 2.30 \\
250 & 7.6933 & - & 2.1741 & - \\
270 & 6.7486 & 9.1 & 2.1725 & 2.39 \\
290 & 6.6310 & - & 2.1153 & - \\
315 & 7.1982 & 8.2 & 2.1021 & 2.19 \\
340 & 8.1776 & - & 2.0335 & - \\
360 & 7.8021 & 8.2 & 2.1844 & 2.05
\end{tabular}


speed of the strongest storm (lasting $6 \mathrm{~h}$ ) during a time interval of interest $(10,50$, 100 years, etc.) is a solution to the inverse problem of determining the value of $U$ from the expression $P_{u>U}=6 / N$. Here $N$ is the number of hours in the specified time interval. Since the data used in estimates of the parameters of the Weibull distribution represent 15 years, the results below can be well used for estimating the maximum wind speed occurring once in 10 or 20 years. Estimates for wind events occurring once during 50 or 100 years should be considered as indicative.

Parameters of the Weibull distribution and extreme wind speeds were calculated separately for each direction. Recorded wind speed maxima during 1977-1991 generally match well the predicted maxima occurring once during 10-20 years (Fig. 5). All the distributions have the two-peaked shape that contains comparable peaks at $\mathrm{SW}$ and $\mathrm{NNW}$ directions, a local minimum at NWW-NW directions, and global minimum at the eastern sector. The largest difference between the recorded and the predicted extreme wind speed occurs for $\mathrm{NE}$ and southern directions where the recorded wind speed maxima are by 2-3 $\mathrm{m} / \mathrm{s}$ lower than the predicted values. This feature is apparently due to the screening effect of the Tagamõisa Peninsula. Evidently, it damps to some extent the strongest winds from this direction, but it does not essentially affect moderate winds that form an unnaturally large portion of the recorded winds. The Weibull distribution takes into account the whole distribution and evidently corrects this damping to some extent. However, it also predicts an uncommonly low east wind speed for the region in question. This feature suggests that east winds at Vilsandi are indeed damped by Saaremaa and that Vilsandi data for this sector poorly match the wind regime at the open sea.

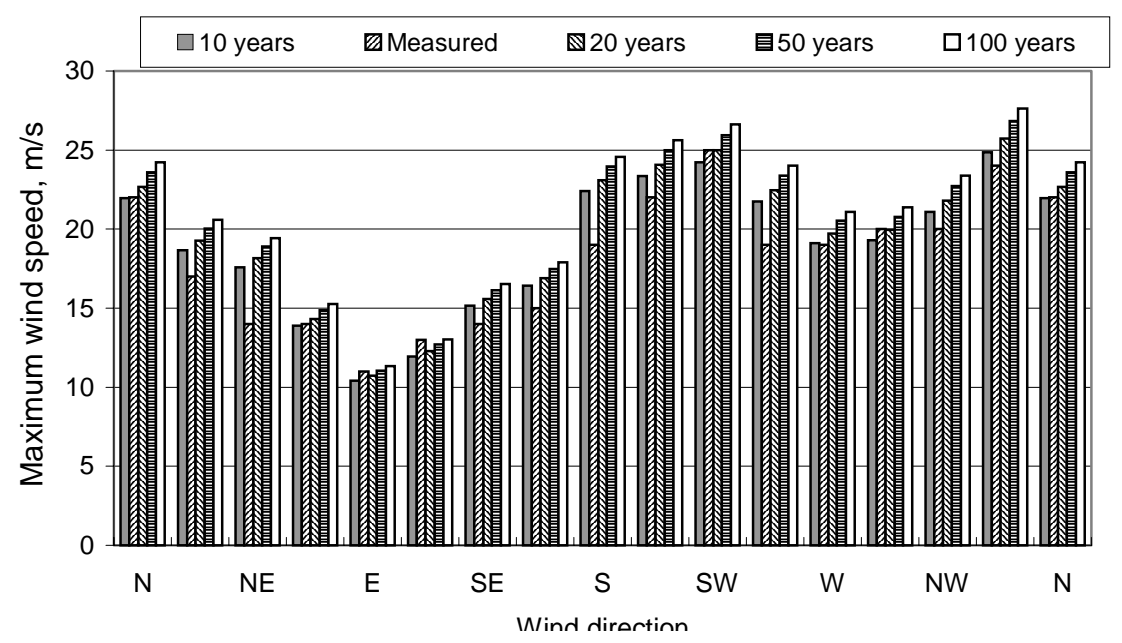

Fig. 5. Angular distribution of the maximum measured wind speed at Vilsandi (1977-1991) and predicted maximum mean wind speed during $6 \mathrm{~h}$ once in a decade, in 20, 50, and 100 years. 
It is interesting to note that several monthly angular distributions of winds at Vilsandi show a sharp minimum at the SW direction $\left[{ }^{10}\right]$. This fact suggests that the only obstacle nearby (a slim lighthouse) introduces certain disturbance into the wind direction. As a result, a part of SW winds are filed as winds from neighbouring sectors and the peak in angular distributions corresponding to SW winds appears as somewhat lower and wider. This peculiarity partially explains why the Weibull distribution predicts stronger NNW winds than SW winds at Vilsandi.

\section{DIRECTIONALLY UNIFORM WIND FIELDS IN THE BALTIC PROPER}

The directional structure of moderate and strong winds in the Baltic Proper, established in $\left[{ }^{10}\right]$ as a purely statistical feature, is heuristically understandable since the dominating winds come either from the direction of global westerlies or match the axis of the basin. In order to make clear if it has some dynamical consequences, it is necessary to compare synchronous recordings of the wind speed at different sites. The data set contains 12622 synchronous recordings during 1980-1983 and 1985-1989 at Vilsandi, Ristna, and Näsudden. In comparisons, only recordings at 0000, 0600, 1200, and 1800 were used from Näsudden data.

Wind speeds at Vilsandi and Ristna are fairly well correlated, correlation coefficient is 0.6729 . This is not surprising since the distance between the sites is about $60 \mathrm{~km}$ and they are located near the eastern coast of the Baltic Proper. The relatively high correlation between wind speeds at Näsudden and Vilsandi/Ristna $(0.4335 / 0.3710)$ indicates that wind speed is comparable at distant sites.

Since the wind speed is a scalar variable and perhaps less affected by various obstacles, comparison of wind directions at different sites apparently identifies better large-scale wind patterns. Straightforward comparison of wind directions is somewhat ambiguous since during calm periods it is poorly defined. In what follows, the comparison has been performed for wind speed components and then interpreted in terms of directions. After excluding calm situations $(u \leq 1 \mathrm{~m} / \mathrm{s})$, the mean difference in wind directions between Ristna and Vilsandi is $23.2^{\circ}$, between Vilsandi and Näsudden $41.7^{\circ}$, and between Ristna and Näsudden $46.1^{\circ}$ (Fig. 6a). (If wind directions at different measurement sites were totally uncorrelated, the mean difference would be close to $90^{\circ}$.) The correlation coefficient for wind directions at Vilsandi and Ristna is 0.639, at Vilsandi and Näsudden -0.363 , and at Ristna and Näsudden -0.319 . Thus, wind direction at Vilsandi and Ristna coincide as frequently as wind speed but wind directions at Gotland and Estonian coast is much less correlated than the wind speeds.

The difference in wind directions drastically decreases for moderate and strong wind events (Fig. 6a). For wind speeds $>10 \mathrm{~m} / \mathrm{s}$, wind directions at Vilsandi and Ristna practically coincide. The mean difference of strong wind directions at Näsudden and Vilsandi is of the order of the angular resolution of 

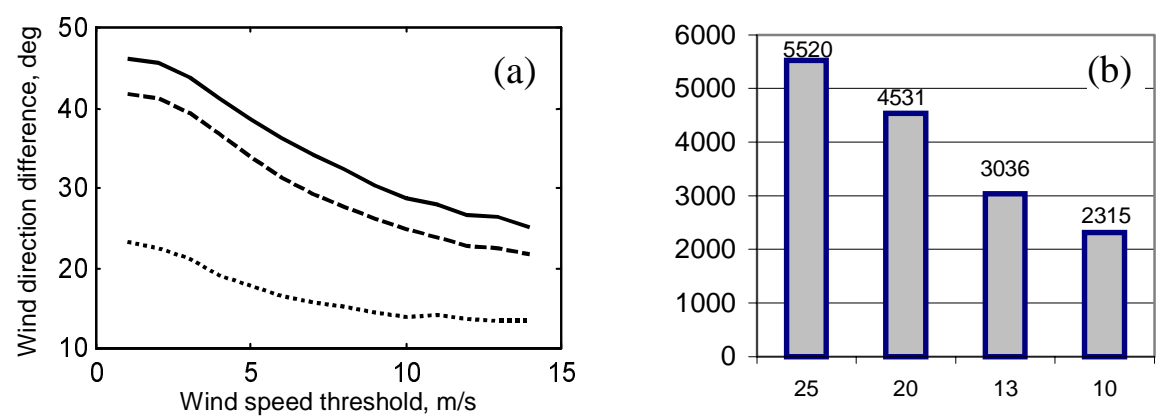

Wind direction difference threshold, deg

Fig. 6. (a) Dependence of the difference of wind directions at different sites on wind speed threshold $\hat{u}$ (i.e. only wind speed $u \geq \hat{u}$ is analysed): - Näsudden and Ristna, ---- Näsudden and Vilsandi, ..... Ristna and Vilsandi; (b) dependence of the number of wind events with close wind directions at Vilsandi and Näsudden (1980-1989, 12622 comparable recordings) on the wind direction difference threshold.

wind measurements at Vilsandi. There is a high negative correlation (close to -0.3 ) between the difference in wind directions and wind speeds at these sites. Thus, strong wind patterns in the Baltic Proper are more uniform than weak find fields. This feature represents the well-known fact that strong storms frequently cover a large area.

Let us call wind patterns with coinciding wind directions at all three sites (directionally) uniform wind events (or uniform wind episodes if they last longer than $6 \mathrm{~h}$ ). The angular resolution of wind direction measurements at Vilsandi and Ristna (1977-1991) was $22.5^{\circ}\left(20^{\circ}\right.$ or $25^{\circ}$, depending on the particular direction, Table 2). Thus, this value serves as an intrinsic threshold of wind direction difference in uniform wind events. Figure $6 \mathrm{~b}$ shows that, quite frequently (about $44 \%$ ), wind directions at Näsudden (where the angular resolution is $1^{\circ}$ ) and Vilsandi differ no more than $25^{\circ}$. The large number of nearly coinciding wind directions (comparable with the number of moderate and strong wind events, Table 1) suggests that among them are many with wind speed $<6 \mathrm{~m} / \mathrm{s}$. This apparently is due to the fact that the sites are open to sea in the western direction and summer breeze has the same direction at these sites. However, the number of wind events with close directions decreases fast if the threshold decreases.

In order to minimize the part of local winds in the analysis below, a wind event is categorized as a uniform one if (1) wind direction difference at Vilsandi and at Ristna does not exceed one step of the angular resolution at these sites, (2) this difference at Näsudden and at Ristna, and at Näsudden and at Vilsandi does not exceed $20^{\circ}$. A uniform wind episode is limited by time moments at which wind direction difference at any pair of the sites exceeds the threshold. More or less uniform wind patterns in the Baltic Sea can be amazingly persistent. Figure 7 demonstrates that in January-February, 1988 wind direction was nearly uniform during a month. Also, Fig. 7 confirms that the stronger the wind, the smaller are variations of the wind direction over the Baltic Proper. 


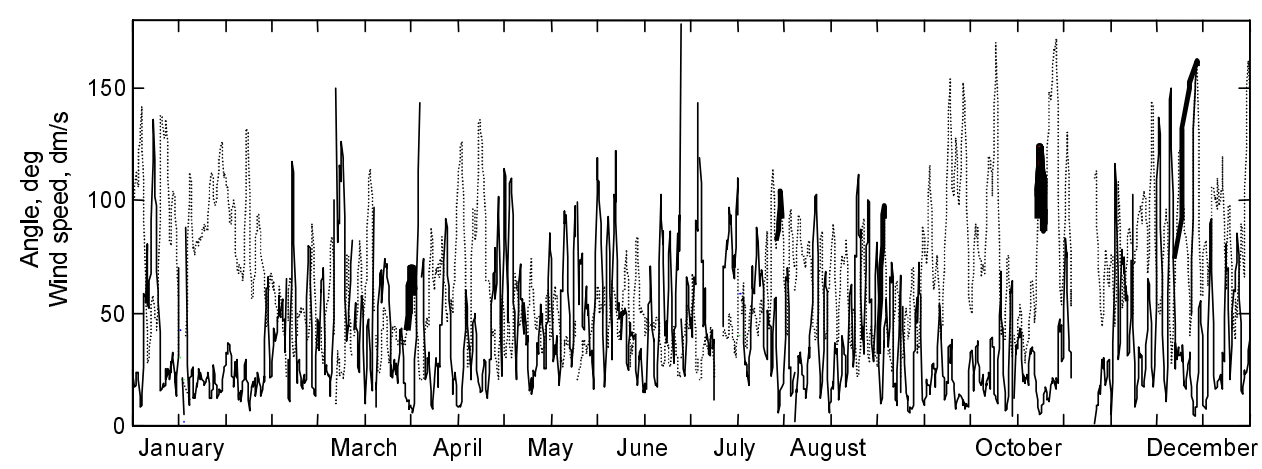

Fig. 7. Wind speed at Vilsandi (dotted curve) and difference of wind directions at Vilsandi and Näsudden (solid curve) in 1988. Heavy solid curve shows wind speed in uniform wind episodes longer than $24 \mathrm{~h}$.
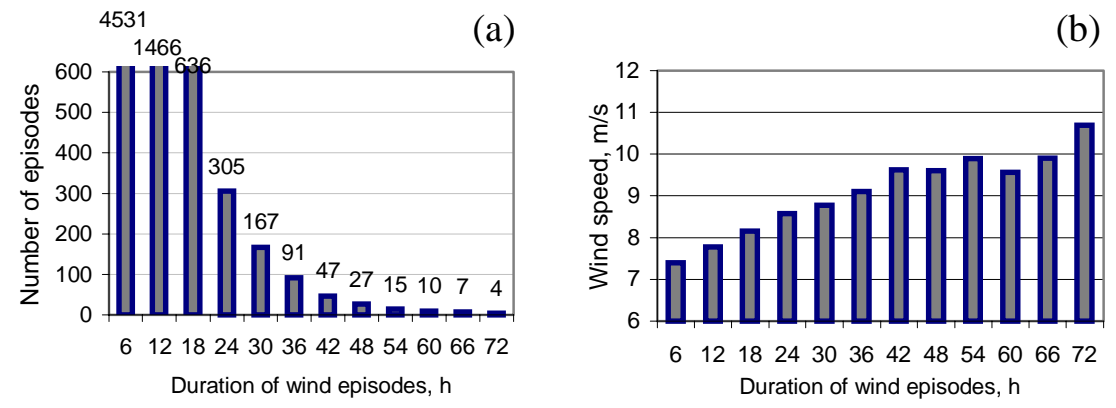

Fig. 8. Number of uniform wind episodes with different duration (a) and mean wind speed in such episodes (b).

Figure 8a shows that the number of uniform wind episodes decreases fast with the increase of their duration. The number of short uniform wind events exceeds three times the number of uniform episodes lasting more than $6 \mathrm{~h}$. Although uniform wind episodes may last several days, very long episodes occurred only a few times in the years 1980-1989. The duration of the longest episode was $108 \mathrm{~h}$ (27.09-01.10.1988). Three others took place on 06.-09.10.1980 (78 h), 23.-26.10.1988, and 25.-28.12.1989 (both 72 h). Episodes with a duration of more than $40 \mathrm{~h}$ are actually long stormy periods with mean wind speed $u_{\mathrm{m}} \sim 10 \mathrm{~m} / \mathrm{s}$ (Fig. 8b).

\section{WIND DIRECTION IN PERSISTENT UNIFORM WIND FIELDS}

An intriguing question is whether the wind direction is constant during uniform wind episodes. Among others, quite impressive are wind data during a 
five-day windy period in October 1988 (following one of the longest uniform wind episodes, Fig. 7). Although wind direction was not constant during this storm, wind speed distributions at Näsudden, Vilsandi, and Ristna show an amazing similarity during the whole period (Fig. 9). Wind speed at Ristna is somewhat less than at other sites. However, its temporal behaviour agrees reasonably with that at Näsudden and Vilsandi except during the first day.

The amazing feature of the storm is its perfect uniformity in direction over the Baltic Proper. Figure 9b demonstrates that wind direction at all three measurement sites was practically identical during five days (except at the 6th, 72nd, and 96th hours of the episode), although the wind itself turned from west to south and then back over west to north. Notice that changes in the wind speed and direction occurred simultaneously. In the final stage of the storm the directional coherence remained, though the wind speed decreased to $2 \mathrm{~m} / \mathrm{s}$ at Ristna. Although extensive study of the wind coherence was not a goal of the present study, it is worth mentioning that a few other randomly chosen episodes were at times also highly coherent.
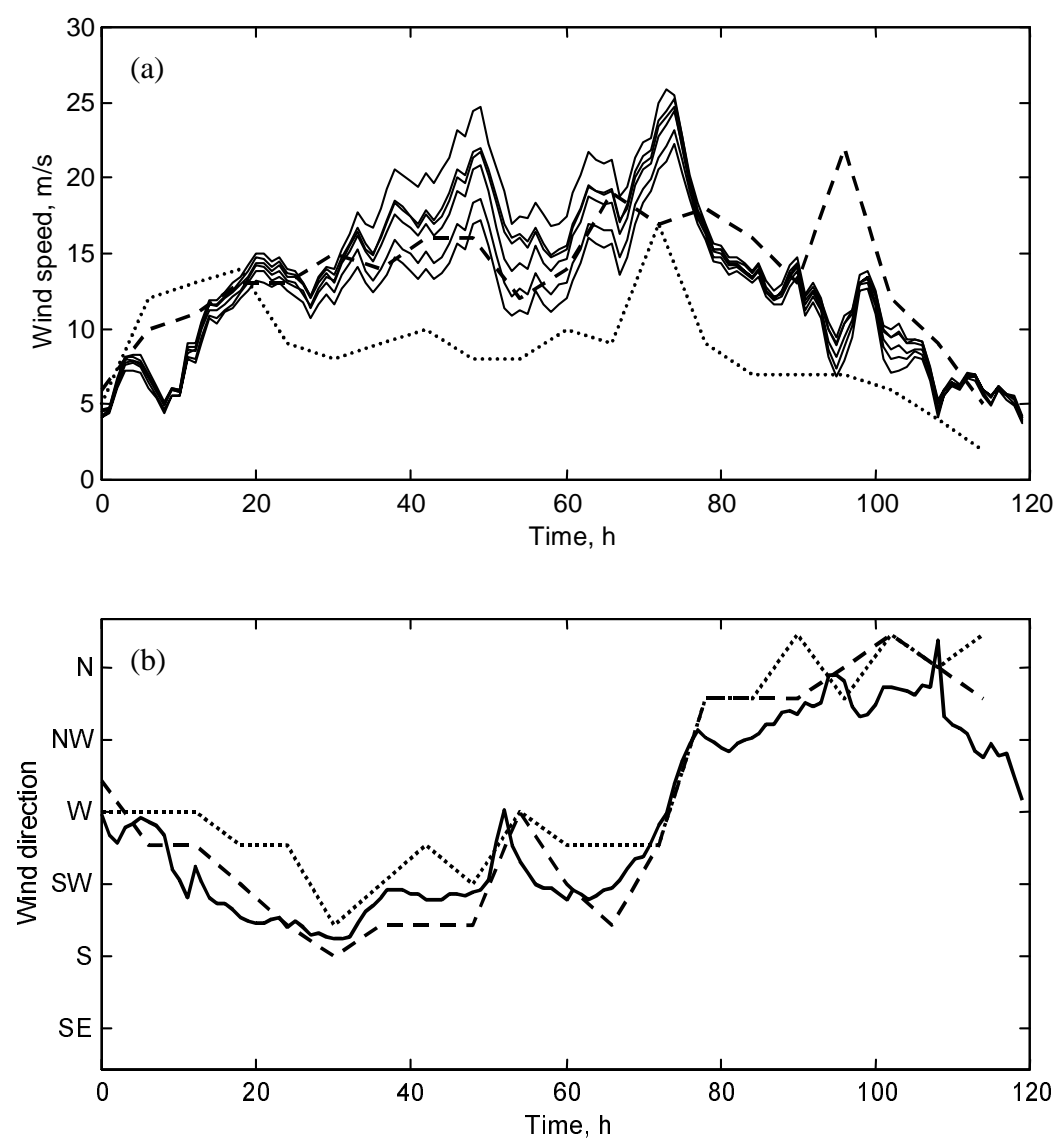

Fig. 9. Wind speed (a) and direction (b) during 26.-30.10.1988; — Näsudden (at different heights), --- Vilsandi, $\cdots \cdot$ Ristna. 
Such long-term coherence, that is preserved even during considerable turns of the wind direction, does not resemble an along-street wind or a low-level jet, one of the possible reasons of frequent prevalence of SW winds among strong wind events $\left[{ }^{10}\right]$. This feature is not typical for local winds like mistral or sirocco that are directionally uniform only because they are constrained to a specific direction. The above-considered wind pattern covers at least $300 \mathrm{~km}$ alongside the wind and behaves as a solid body since the changes in the wind direction were simultaneous. Traditional concepts of storms caused by low pressure areas or by atmospheric frontal zones hardly can explain such long-term wind coherence, in particular, in the Baltic Sea area where mesoscale effects typically govern the wind field.

The synchronous turns of the wind direction are unexpected events in the area in question. Wind measurements at Harilaid Islet in the Moonsund area in 19971998 demonstrated that, at least, "during two first days rapid change of the wind speed on Harilaid and Tahkuna (separated by less than $100 \mathrm{~km}$ ) never coincided" $\left[{ }^{13}\right]$. Certain time shift between wind direction changes at separated sites is a rule since, generally, flow disturbances (incl. those causing turning of the wind direction) are transported either with the flow speed or propagate like waves in the medium, with certain phase speed. The velocity of the disturbance causing the short-time turn in wind directions at the 50th hour of the event is, at least, a few hundreds kilometers per hour, i.e., comparable with the sound speed.

\section{DISCUSSION}

The anisotropy of the directional distribution of wind properties and the existence of the dominating direction of moderate and strong winds in the Baltic Proper results in an immense angular variation of the extreme wind speed. Consequently, maximum wave heights and wave loads at different areas of the Baltic Proper may be radically different. However, if dangerous waves are restricted to a single direction, it is relatively inexpensive to protect harbour areas against high waves.

The frequent occurrence of large-scale persistent wind episodes with a uniform wind field is a natural consequence of the anisotropic wind regime $\left[{ }^{10}\right]$. Indeed, if strong winds are restricted to a single direction, wind direction in geographically separated sites may easily coincide. The increasing uniformity of the wind field with increasing mean wind speed is consistent with the fact that directional distribution of strong wind events is more anisotropic than that of moderate winds and confirms that the stronger a storm, the larger area it covers.

The distinguishing feature of several spatially uniform wind patterns is that they may persist for several days. Both the wind speed and direction may greatly vary but the wind field remains coherent. Even minor changes in the wind direction occur simultaneously at distant measurement sites, a feature which is not straightforward to interpret. Since the wind direction changes more than 
$180^{\circ}$, the patterns apparently cannot be related to jet-like structures. Such episodes of spatially constant wind may dramatically accelerate wind wave generation intensity since fluctuations of the wind direction generally lead to a certain decrease in wave heights $\left[{ }^{19}\right]$. Properties of the wave generation are normally measured during fluctuating (in speed and direction) wind episodes. Frequent occurrence of spatially constant wind fields may be one of the reasons why wave models sometimes underestimate wave heights during storms in the Baltic Sea $\left.{ }^{20,21}\right]$.

Long-lasting winds along the Baltic Sea axis may create essential deviations of the water level. If strong wind turns or ceases abruptly, the following oscillations and accompanying currents have considerable amplitudes. Although turning wind itself generally reduces wave heights, interaction of waves and intense currents may essentially modify the surface wave field. After rapid changes of the wind direction, "fresh" waves no more propagate downstream and their interaction with currents generally results in steepening of the wave profiles. In extreme cases, appearance of freak waves is possible $\left.{ }^{22}\right]$. In the cases analysed, wind direction mostly turns clockwise from SW over west to north. Thus the angle between the wind and the wind-generated current decreases. However, the current (in the case of initial SW wind it is directed to east or SE) generally creates inertial oscillations if the forcing ceases. Their period in the Baltic Sea is about $14 \mathrm{~h}$ and after 7-8 $\mathrm{h}$ the current reverses to NW. If there happens to be strong NW wind at this time, it generates waves travelling exactly against the inertial current. This mechanism may be one of the reasons why NW storms are generally believed to be the most dangerous although they are less frequent and weaker than SW storms.

\section{ACKNOWLEDGEMENTS}

This paper was initiated in the framework of hydrodynamical and geological studies of the possible locations of the Saaremaa deep harbour (financed by the Estonian Centre of Environment Studies) and partially supported by the Estonian Science Foundation (grant No. 4025). The author is grateful to Estonian Maritime Agency (T. Kõuts) and Department of Meteorology, Uppsala University (S. Zilitinkevich, M. Mohr) for presenting the wind data.

\section{REFERENCES}

1. Hoskins, B. J. and Valdes, P. J. On the existence of storm-tracks. J. Atmos. Sci., 1990, 47, $1854-1864$.

2. Rogers, J. C. North Atlantic storm track variability and its association to the North Atlantic oscillation and climate variability over Northern Europe. J. Climate, 1997, 10, 1635-1647.

3. Prilipko, G. I. (ed.) Climate of Tallinn. Gidrometeoizdat, Leningrad, 1982.

4. Kull, A. Eesti tuuleatlas. M.Sc. thesis. Tartu University, Tartu, 1996.

5. Eesti NSV kliimaatlas. Tallinn, 1969. 
6. Handbook of Climate of the USSR, Vol. 4: Estonian SSR, Part 3: Wind. Gidrometeoizdat, Leningrad, 1966.

7. Bergström, H. Distribution of Extreme Wind Speed. Wind Energy Report WE 92:02. Dept. of Meteorology, Uppsala University, 1992.

8. Bergström, H. A Climatological Study of Wind Power Potential in the Blekinge Area Using a Meso- $\gamma$-scale Higher Order Closure Model. Wind Energy Report WE 92:01. Dept. of Meteorology, Uppsala University, 1992.

9. Kõuts, T. Forcing factors for hydrography and currents - meteorological and hydrological variables. In The Gulf of Riga Project (funded by The Nordic Council of Ministers). SMHI, Norrköping, Sweden, 1998 (CD-ROM).

10. Soomere, T. and Keevallik, S. Anisotropy of moderate and strong winds in the Baltic Proper. Proc. Estonian Acad. Sci. Eng., 2001, 7, 35-49.

11. Petersen, E. L., Troen, I., Frandsen, S., and Hedegaard, K. Windatlas for Denmark. Ris $\varnothing-\mathrm{R}-428$, Ris $\varnothing$ National Laboratory, Denmark, 1981.

12. Persson, C. and Kindell, S. Nederbördens beroende av den geostrofiska markvinders och den verkliga vindens riktning. Meddelande No. 8, SMHI, Norrköping, 1981.

13. Tomson, T. and Hansen, M. Wind dynamics in the Moonsund Archipelago. Proc. Estonian Acad. Sci. Eng., 2000, 6, 61-69.

14. Tomson, T. Periodical component of the West Estonian wind. Proc. Estonian Acad. Sci. Eng., $2001,7,50-57$.

15. Kõuts, T. and Laanearu, J. Variability of currents in bays of Tagalaht and Uudepanga. Proc. Estonian Acad. Sci. Eng., 2001, 7, 126-140.

16. Soomere, T. Wave regimes and anomalies off north-western Saaremaa Island. Proc. Estonian Acad. Sci. Eng., 2001, 7, 157-173.

17. Troen, I. and Petersen, E. L. European Wind Atlas. Ris $\emptyset$ National Laboratory, Roskilde, Denmark, 1989.

18. Mohr, M. and Sandström, S. A Comparison Between Measurements and Simulations with WASP and the MIUU Model. Wind Energy Report WE 96:01. Dept. of Meteorology, Uppsala University, 1996.

19. Komen, G. J., Cavaleri, L., Donelan, M., Hasselmann, K., Hasselmann, S., and Janssen, P. A. E. M. Dynamics and Modelling of Ocean Waves. Cambridge Univ. Press, Cambridge, 1994.

20. Kahma, K., Pettersson, H., Stipa, T., Högström, U., Smedman, A. S., and Bergström, H. Comparison of Wind Stress Hindcast by a Coupled Atmospheric-wave Model (ECAWOM) and the Measured Wind Stress at Östergarnsholm. Technical Report. Finnish Institute of Marine Research, Helsinki, 1997.

21. Tuomi, L., Pettersson, H., and Kahma, K. Preliminary results from the WAM wave model forced by the mesoscale EUR-HIRLAM atmospheric model. In Workshop on Modelling of the Marine-atmospheric Boundary Layer. Helsinki, 7-8 December 1998. Report Series of the Finnish Institute of Marine Research, 1999, 40, 19-23.

22. White, B. S. and Fornberg, B. On the chance of freak waves at sea. J. Fluid Mech., 1998, 355, $113-138$.

\section{EKSTREEMSED TUULE KIIRUSED JA KONSTANTSE SUUNAGA TORMID LÄÄNEMEREL}

\section{Tarmo SOOMERE}

On näidatud, et Vilsandi meteojaama tuuleandmed peegeldavad hästi Läänemere avaosa režiimile iseloomulikke tuule parameetreid (nii keskmist kiirust kui ka tuule jaotust ilmakaarte järgi). Weibulli jaotuse kaudu arvutatud tuule maksi- 
maalkiiruse jaotusel ilmakaarte järgi on kaks tippu, mis vastavad edela- ja põhjatuultele ning sügav miinimum idakaarte tuulte puhul. Artiklist järeldub, et sageli esineb Läänemere avaosas pikka aega kestvaid tuuli, mille suund on konstantne laialdasel alal. Tuule suund võib sellistes tormides muutuda suurtes piirides, kuid suuna muutused toimuvad sünkroonselt. 
